\title{
Critical Realignments and the Public Opinion Poll
}

\author{
John G. Geer \\ Arizona State University
}

With the advent of the public opinion poll, politicians began to have access to highly reliable information about the electorate's views on issues. Prior to this development, party leaders could only make educated guesses about public opinion. These guesses, however, were often incorrect, since they were based on unsystematic evidence. But armed with polls, parties should avoid such errors, approximating Downs' (1957) assumption of certainty. If so, rational parties should converge near the center of the distribution of public opinion. Or in other words, parties should no longer polarize on highly salient issues that confront the nation.

This conclusion has important implications for the study of partisan realignments. The best work on the subject by scholars like Sundquist (1983) and Carmines and Stimson (1989) argue that one requirement for a realignment is that the parties must polarize on an issue of high salience to the public. Yet well-informed, rational parties should not engage in such behavior, suggesting that critical realignments may be things of the past. Note that partisan change still occurs-perhaps along the lines of Key's (1959) notion of secular realignment or Carmines' and Stimson's (1989) concept of "issue evolution."

$\mathbf{U}_{\mathrm{n}}$

ntil recently politicians have operated under conditions of great uncertainty when deciding what positions to take on issues. They had only rough guesses about public opinion, which stemmed from such things as the results of the prior election, attendance at political rallies, and editorials in local newspapers. With the development of the public opinion poll, however, politicians began to have access to highly reliable information about the electorate's views. Now, with better sampling techniques and improved question wording, polls provide politicians with more useful information than at any other time since the extension of mass suffrage in the nineteenth century. ${ }^{1}$

I would like to thank Thad Brown, Pat Crittenden, Rich Dagger, Rick Herrera, Tom Rochon, Harold Stanley, Doug Van Belle, and Steve Walker for assistance on earlier drafts of this paper. An earlier version of this paper was presented at the 1988 APSA meetings.

${ }^{1}$ Kelley (1983) observes that prior to the 1800 s politicians may have possessed a good deal of information about voters' views. During that period, electorates were small and voting was public. Under those conditions, local politicians may have been able to learn first-hand about voters' preferences. The expansion of the eligible electorate and the adoption of the secret ballot altered the situation, however. It was not until the development of survey research that politicians once again had access to what voters thought about various issues and candidates.

Journal of Politics, Vol. 53, No. 2, May 1991

(C) 1991 by the University of Texas Press 
This development should affect the behavior of politicians and parties. For instance, party leaders should be able to write platforms that are more in line with public opinion. When forming strategy for a campaign, candidates and their staffs should have a better idea of what plans will work and what will not. The party leadership should also know more about the electoral prospects of candidates in the general election, which will allow them to support the most electable contenders.

Another important implication stemming from the development of the public opinion poll, which is the subject of this paper, is that parties should no longer form sharp disagreements with their rivals on issues that are highly salient to the electorate. Recall that Downs (1957) shows that rational parties operating under conditions of perfect information will converge at the center of the distribution of opinion. Of course, polls do not provide perfect information. But polls should provide office-seeking politicians with enough quality information to keep them from staking out vastly different positions on issues of high salience to the public. In other words, rational parties will no longer adopt polarized positions on issues of great importance to the electorate.

This conclusion has important implications for the study of partisan realignments. Most scholars agree that a crucial ingredient in any realignment is that the parties must stake out clearly different positions on issues of high salience to the public (Burnham 1970; Sundquist 1983; Carmines and Stimson 1981, 1984, 1989). Without polarized parties, citizens lack the incentive to alter existing partisan attachments or to form new ones. Now, however, rational parties, knowing the public's views on highly salient issues, should not adopt vastly different positions on those matters. Consequently, the public opinion poll may have fundamentally altered the process of partisan change, casting a monkey wrench into our theories of realignment. No longer should we expect sharp, durable changes normally associated with periods of "critical" realignments. Instead, partisan change will be more gradual, perhaps along the lines of Key's (1959) notion of secular realignment or Carmines' and Stimson's (1989) concept of "issue evolution."

On the surface, at least, this argument has some appeal. Since the mid1960 s, political scientists have been expecting a realignment of the party system. Yet that event has not occurred. Of course, some scholars view the absence of such change as evidence that the concept of realignment is flawed (see especially Carmines and Stimson 1989). While there are problems with the concept, this paper offers an alternative explanation for why there has not been a period of rapid partisan change since the 1930s.

\section{A Spatial Conception of Realignment}

The logic of spatial modeling is well suited for the study of partisan realignments. One can, quite simply, view a realignment as a change in the 
distribution of voters' preferences. That is, the midpoint of the distribution shifts to either the left or the right in response to some political event, such as an economic depression or a war. This shift, however, must be "sharp and durable" before it can be considered a realignment (Key 1955, 16). Political scientists agree that the minor fluctuations in public opinion accompanying most elections do not constitute a realignment. Consequently, a realignment in a Downsian world would be a significant shift in the distribution of voters' preferences that will last over a series of elections. ${ }^{2}$

This conception of realignment is consistent with most previous theories. In fact, the literature on realignment is replete with references that are spatial in nature. Burnham $(1970,7)$, for instance, argues that in a realignment "issue distances between the parties are markedly increased." The notion of "issue distances" fits with the reasoning behind spatial modeling. Sundquist (1983, 14), on the other hand, views a realignment as "those redistributions of party support, of whatever scale or pace, that reflect a change in the structure of party conflict and hence the establishment of a new line of partisan cleavage on a different axis within the electorate." The phrases "partisan cleavage" and "axis within the electorate" are also consistent with a spatial representation. Clubb, Flanigan, and Zingale $(1980,31)$ argue that a realignment involves the "formation of a new distribution of partisan loyalties in the electorate." The idea of a "distribution" fits within a spatial framework. Finally, Carmines and Stimson (1989) contend that highly salient issues help forge partisan change in the electorate. Again, one can conceptualize the idea of a "highly salient issue" in spatial terms.

While there are similarities between previous definitions and this Downsian conception, at least one important difference emerges. For Sundquist (1983) and Schattschneider (1975), a realignment involves two-dimensional space. That is, a realignment occurs when a highly salient issue cuts across the existing political continuum. Yet under the definition posited above, a realignment is a sharp and durable shift in the existing distribution of opinion. Aldrich (1983) actually uses the idea of a cross-cutting issue, building a multidimensional model to capture the process of realignment.

For this paper, however, I shall adopt the simpler unidimensional assumption. While this choice at first glance may appear problematic, it is defensible. If one thinks of the political continuum not as representing the public's

${ }^{2}$ I am being vague about what constitutes "significant" and "durable." The literature is also vague on this subject (Sundquist 1983, chap. 1). One could set precise standards, but such an exercise would be arbitrary. For instance, assume that durable means that the change must last at least four elections. But just prior to the third election under a new party arrangement, war breaks out. This conflict alters the partisan views of the electorate. While the attitudes prior to the war were entrenched, the trauma of that military conflict changed them. So, just because the change did not last four elections, does that mean we should not consider that earlier shift to be a realignment? As one can see, this issue is sticky. 
view on a particular realigning issue, but rather as a representation of a whole array of concerns, then a cross-cutting issue can be worked into this Downsian definition. That is, whatever dominant issue confronts the country, whether it be slavery or government intervention in the economy, voters can still be aligned along a single dimension that will incorporate that issue. The distribution of opinion, therefore, represents the summation of voters' preferences on a large number of issues. And when an issue arises of great importance to the electorate, it can dramatically alter the shape of that distribution.

Sundquist $(1983,204)$, ironically, lends support for the view that a realignment can be viewed within a single dimension, as indicated by his description of the 1930s realignment: "The Hoover of 1928 may have been a moderate centrist, in the political spectrum of that time, but in four years of calamity the whole spectrum moved sharply to the left. By 1932 the center had slipped from under the president and had stranded him, his heels dug in, at the extreme. And his party, save for its insurgent minority, was stranded with him."

While one may still be dissatisfied with the unidimensional assumption, the idea that voters are aligned along a single continuum is, at least, more realistic for the study of realignments than for the study of specific elections. As we know, parties compete on a variety of issues in any given election. Yet Downsian models often assume just a single dimension. This simplification has, of course, drawn much criticism (see, for instance, Stokes 1966). But despite these reservations, this simple model has provided a powerful explanation for the behavior of parties. And since realignments involve the struggle between the parties on some highly salient issue, such as governmental activism, the unidimensional assumption should be able to provide a compelling account of how parties behave during periods of rapid partisan change.

\section{Motivation of Parties}

With a spatial conception of realignment in place, I now turn to the question of what motivates the behavior of parties. Downs (1957) originally assumed that parties seek only to win elections and that views pertaining to public policy are simply a means of gaining votes. Over the last two decades, however, the traditional assumption that parties are not concerned with policy has come under attack (see, for instance, Schlesinger 1975; Wittman 1973, 1983; Chappell and Keech 1986; Herrera 1989). As Wittman (1983, 142) observed, "in the real world candidates are both office oriented and issue oriented." One need only look at the array of data presented by Miller (1988) to see that the leadership of the parties are indeed concerned about public policy. 
For the purpose of this paper, however, I shall assume that parties are solely concerned with winning elections. Given that this paper deals with realignment, the assumption is reasonable. While parties, as noted above, have concerns about policy, a "realigning" issue alters their calculations. If a party in the face of a realigning issue adopts its preferred position rather than the electorate's preferred position, it risks establishing itself as the minority party. In that weakened position, a party's chances of gaining office (and pursuing public policy) are greatly diminished. Thus, a rational party (whether motivated by policy or not) must pursue a vote-seeking strategy when confronted with a realigning issue or risk being denied access to government on a long-term basis.

Wittman (1983) offers support for this position, arguing that as a policy becomes more important in affecting the outcome of the election, the more a party will move away from its preferred position, if necessary. And since realigning issues can alter the very fabric of an election (and even future ones), rational parties are very likely to behave in the classic Downsian manner when addressing such concerns.

In addition, if one assumes that parties are interested in pursuing a variety of different policies, it makes even more sense for rational parties to sacrifice their own views on a realigning issue. While that issue is, by definition, central to voters, it is likely to be only one of many issues of consequence to the parties. Thus, by adopting a vote-maximizing strategy for realigning issues, parties may then be able to position themselves closer to their own views on issues of less salience to the public.

In sum, while parties have policy objectives, it seems reasonable to assume that parties are solely interested in vote-maximizing when it comes to an issue that threatens to realign the party system.

\section{A Downsian Account of Realignment}

In chapter 8, Downs (1957) examines how vote-seeking parties will compete with each other under different conditions. One of the more famous conclusions is that parties will converge at the midpoint in the distribution of voters' preferences (see diagram 1). ${ }^{3}$ This conclusion applies to a stable political system; that is, a system where the distribution of voters' preferences remains the same. But as noted above, a realignment involves a significant

\footnotetext{
${ }^{3}$ Parties will not, however, offer identical platforms. If parties adopt the same views on issues, rational voters will lack the incentive to turn out since it will not matter which party wins the election. Thus, parties have reason to differentiate themselves a little bit. Empirically this appears to be the case. While the Democratic and Republican parties often adopt similar views on issues, the positions are rarely identical. Smithies (1941) was the first to introduce the idea that elasticity will provide firms (parties) incentive to present slightly different products (platforms) to the public.
} 


\section{DiAgram 1}

Downs's Classic Model of PaRty Competition

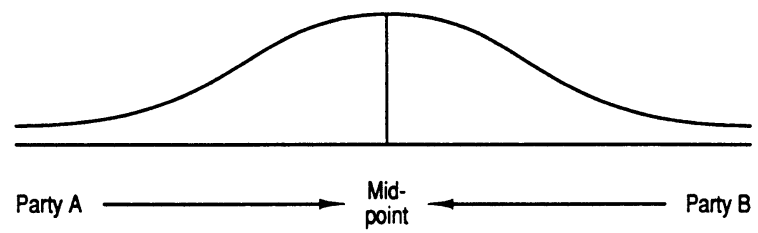

See Downs $(1957,118)$.

\section{DiAGRAM 2}

\section{Parties' Reaction to Shift in Public Opinion}

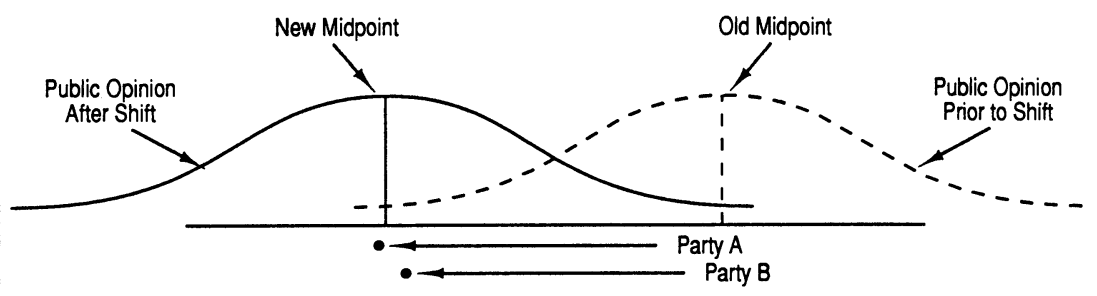

and durable change in the distribution of public opinion. When such a change occurs, however, rational parties should still compete at the center of the distribution by rapidly adjusting their position in an effort to maximize support (see diagram 2). The parties, therefore, should quickly adopt similar positions in the new distribution of opinion in order to maximize votes.

But if parties adjust quickly and thus continue to offer similar views along 
this dimension, the electorate will not have sufficient incentive to adopt new partisan loyalties. As Sundquist $(1983,302)$ argues, "unless and until there is a clear and significant difference in the positions of political parties on an issue, there is no reason for persons aroused by that issue to shift party loyalties, or, among those new to the electorate or politically independent, to choose to identify with a party." Consequently, the rational behavior of voteseeking parties should prevent large shifts in the partisan attachments of the electorate. In other words, Downsian logic indicates that critical realignments should not occur.

Yet there have been periods of significant partisan change in U.S. history, which contradicts this account of realignment. However, there is an important assumption underlying this Downsian analysis: namely, that both parties have complete information about public opinion. When parties know the distribution of opinion, they can position themselves to maximize their support. But during past realignments, parties did not have complete information. Politicians could estimate public opinion, but their guesses were fraught with error (Nimmo 1970; Mendelsohn and Crespi 1970; Sabato 1981). In addition, parties often relied on vastly different sources of information to make decisions. One party might, for instance, use the reaction of the crowd to a candidate's speech, while the other party might pay more attention to what local politicians thought was the mood of the public. Parties, therefore, could easily differ in their interpretation of the public's position on an issue, leading them to take opposing viewpoints. ${ }^{4}$ Note that these positions would still be "rational," given the parties' information about public opinion at the time.

Thus, when a highly salient issue confronted the public and the parties had different perceptions of the electorate's views, critical realignments were possible. Under these circumstances, voters could perceive differences between the parties, leading them to develop a commitment to the party that better represented their views. Diagram 3 illustrates this process of partisan change under conditions of imperfect information. In this new alignment, the majority party (A) correctly gauged public opinion, while the minority party (B) made an error in political judgment. ${ }^{5}$

\footnotetext{
${ }^{4}$ Calvert (1985) argues that whether candidates operate with certainty or uncertainty, convergence to the median voter still occurs-a conclusion which on the surface contradicts my account of how parties can polarize on issues. It turns out, however, that my notion of uncertainty differs from Calvert's. For him, even when politicians lack perfect information, both parties still possess the same, although flawed, view of the electorate. My point, in contrast, is that prior to polls, politicians not only lack good information about voters' views, but also periodically developed different perceptions of the electorate's position on these issues. It is these differing perceptions of the electorate that led to polarization.

${ }^{5}$ Note that in diagram 3 parties exhibit more mobility than is usually permitted in models of party competition. As Downs $(1957,122)$ argued, "political parties cannot move ideologically
} 


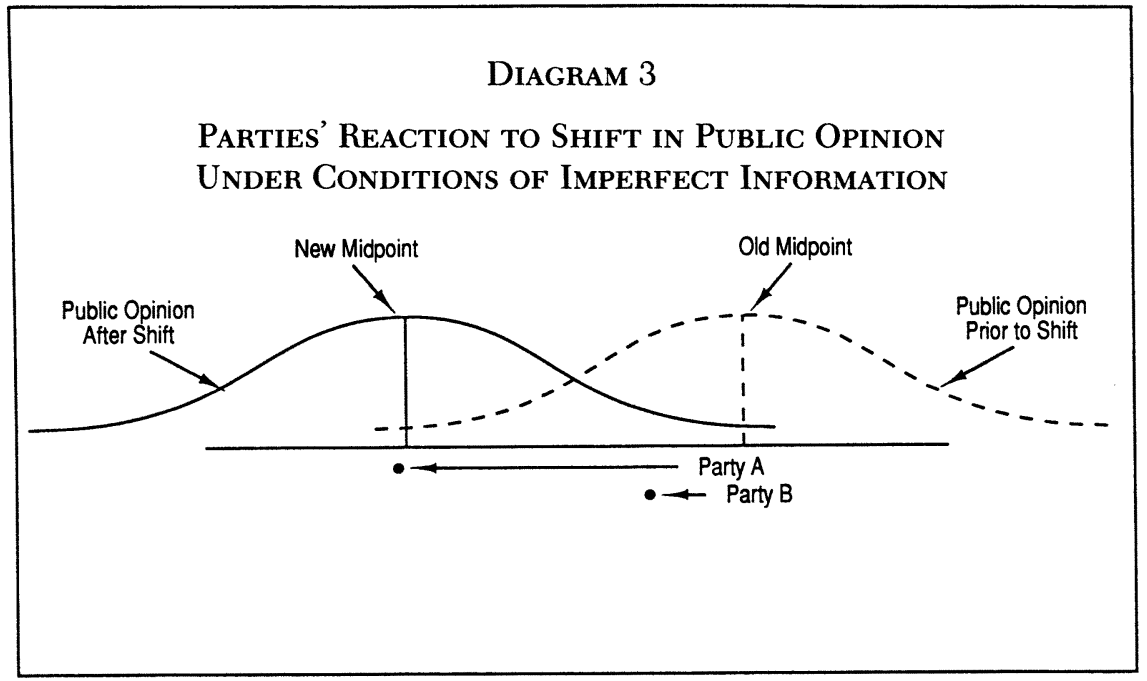

In sum, critical realignments can be viewed as products of the judgments of poorly informed politicians who mistakenly lead their party away from the center of public opinion. ${ }^{6}$

Obviously, one cannot test this model, since there is no way to know whether politicians of the past would have acted differently with access to polls. But there are some examples from history that are suggestive. In the

past each other. ... (I)ntegrity and responsibility create immobility, which prevents a party from making ideological leaps over the heads of its neighbors." But in periods of realignments, the political situation is likely to be in flux. Some large issue dominating the public's agenda may allow parties greater freedom than in periods of political calm. Downs $(1957,110)$ actually suggests this possibility when stating that "ideological immobility is characteristic of every responsible party, because it cannot repudiate its past actions unless some radical change in conditions justify this." Periods of war or depression can be thought of as the "radical change" that justifies allowing parties greater mobility.

${ }^{6} \mathrm{Clubb}$ and associates (1980) and Kleppner (1987) offer a competing explanation for realignments that questions whether the "mistakes" of politicians could generate partisan change. They contend that realignments are the result of one party adopting policies that solve some political trauma facing the nation. Thus, the realignment in the 1930s only became reality once FDR's policies were perceived as effective by the electorate.

While their arguments have much merit, the role of polarization can still be central in the process. That is, if the GOP had offered programs that looked very much like the Democrats in 1936, the electorate would not have been offered such a clear choice. And under that condition, the degree of partisan change might well have been lessened. I am not suggesting that the GOP could have won the 1936 presidential election; rather, that the Republicans might have been able to avoid becoming the minority party.

Obviously, one can only speculate here. My point, however, is simply that one of the central ingredients in a realignment involves the polarization of parties on a highly salient issue. 
realignment of the 1930s, for instance, the parties polarized over the role of the federal government in the economy. These disagreements surfaced quite clearly in the presidential election of $1936^{7}$ - a time when the best available measures of public opinion sent mixed signals about the electorate's willingness to support FDR's programs. The Democrats had scored major victories in the 1934 midterm congressional elections, suggesting that their programs were popular with the electorate. Yet by 1935 , there was evidence that an anti-New Deal sentiment was growing in the country (see Schlesinger 1960). The Republicans, for example, had captured the New York State Assembly, which many political observers interpreted as a defeat for the New Deal. As FDR's campaign manager, James Farley (1938, 291), recounts: "The Democrats fared rather badly in a few of the state elections that year, and naturally those minor victories were hailed by the opposition as a trustworthy sign of shifting political winds" (my emphasis). In addition, the now famous Literary Digest Polls showed that Landon and the Republicans could win the 1936 election, further indicating that the New Deal may have been waning in popularity (McCoy 1966, 264). These kinds of mixed signals may have helped fuel the belief of old guard Republicans that the public was not supportive of the New Deal (Schlesinger 1960; Weed 1989), encouraging them to remain committed to their long-standing views on government intervention.

The realignment of the 1890 s may also be attributable to politicians' relying on flawed measures of public opinion. William Jennings Bryan apparently had good reason to believe that his strong support of free silver would lead him to victory in 1896. Many of Bryan's campaign speeches drew enormous crowds (Jones 1964; Hollingsworth 1963), indicating a possible groundswell of support for free silver. Anderson (1981), for instance, reports that Bryan "spoke to crowds of 50,000 in Columbus, 10,000 in Springfield, and

${ }^{7}$ In 1932, the Democrats and Republicans showed little disagreement over most matters of policy (Page 1978). The Democrats, for instance, were quite vague about how to solve the Depression. By 1936, however, polarization arose between the parties. The GOP in that year's platform criticized the New Deal for usurping "the rights reserved to the states and to the people" and calling for the return of relief programs to local authorities (Johnson and Porter 1973, 365-66). This same document also attacked the New Deal's effort to create government jobs as a temporary and costly solution to unemployment. All in all, the Republican party in 1936 was committed to relying "on the character and virtue, self-reliance, industry and thrift of the people," not "on the wisdom and power of the government" (Johnson and Porter 1973, 370).

The Democrats, by comparison, produced a platform in 1936 committed to an activist federal government. The platform supported the federal government's role in helping the unemployed, farmers, senior citizens, labor, those stricken by natural disasters, and individuals who faced foreclosure on their homes (Johnson and Porter 1973, 360-63).

The Democrats clearly adjusted their position in the few years after the 1932 election. And since the Republicans remained committed to minimizing the federal government's role in the economy, polarization of the parties emerged over that issue. 
40,000 in Toledo, all in McKinley's own Ohio." Anderson $(1981,90)$ then notes that "so large were his crowds elsewhere that predictions of his victory were commonplace, the New York Herald anticipating in October that he would win 237 electoral votes, thirteen more than sufficient for election." Bryan also received numerous letters from voters-a further testimony to his popularity (Colletta 1968). These kinds of measures gave Bryan reason to believe he was hitting a responsive chord with the public. The problem is that these judgments were based on unsystematic data, which gave Bryan a plausible but mistaken belief that the issue of free silver would provide him a majority of the electorate's support. ${ }^{8}$

Surely, there were signs indicating that Bryan and Landon were making mistakes, since FDR and McKinley steered their parties on the correct course. But the point is that given the kind of information available, one could easily develop vastly different interpretations of public opinion. These interpretations were no doubt molded, in part, by the predispositions of these politicians. That is, given Bryan's support of free silver, he and his aides looked for evidence indicating that the public supported their position. With the availability of public opinion polls, politicians should now be able to avoid these kinds of mistakes. Consider Ronald Reagan. All indications are that he personally supported making social security voluntary (Drew 1981, 263-64, 298). Yet despite this view, Reagan contended that he supported a safety net for the less fortunate in the 1980 campaign and even promised an increase in benefits (Drew 1981, 308). The difference between Reagan's rhetoric and his personal view may have been attributable to Richard Wirthlin, his pollster, who showed him hard evidence that the public would not support making social security voluntary. Without Wirthlin's polling data Reagan may have been swayed by his own personal views and by the large and supportive crowds that would surely have come to hear him express those views, which might have encouraged him to polarize the parties on the issue of social security.

We will, of course, never know whether these interpretations are correct. But the scenarios at least seem plausible. There is one thing of which we can be confident: polls have become an integral part of all national campaigns and politicians respond to the information they supply. As early as 1939, FDR used information from polls to make political decisions (Roll and Cantril 1972). In 1952, Eisenhower's aides relied on polls to shape the content of their television advertisements (Sabato 1981, 69). Nowadays polls dominate the conduct of national campaigns. Reagan's campaign strategy against Jimmy Carter was shaped directly by information from polls (Wirthlin, Breglio, and Beal 1981). Gary Hart literally built his 1984 campaign theme of

\footnotetext{
${ }^{8}$ For an interesting account of the mistakes parties made in assessing public opinion in the pre-Civil War era, see Gienapp (1987).
} 
"new ideas and new leadership" from a poll conducted by Pat Caddell. Most recently, George Bush's attacks against Michael Dukakis were based on information culled from surveys.

Polls, of course, are not the only source of information politicians use, but they may be the most important. As Robert Teeter, Ford's director of research in the 1976 presidential election, observed: "There were two kinds of considerations: first, some conclusions we drew ourselves about the strengths and weaknesses of the president as a campaigner; second, the perceived differences between the candidates as shown by our polling data. The second group of considerations was the most important in our discussions with the president and in our campaign planning after the convention" (Moore and Fraser 1977, 119). In short, politicians clearly rely on (and will continue to rely on) public opinion polls to make political decisions, which should result in minimizing the differences between the parties on matters of high salience to the public.

\section{Possible OBjEctions}

One might argue that even with the availability of polls, parties will still periodically polarize on highly salient issues. For instance, while survey research provides better information than was available to politicians prior to the 1940s, polls simply do not supply anything close to "perfect" information. Polls produce different results from time to time because of different sampling designs, wording of questions, or just random error. These kind of differences might fuel polarization. In addition, politicians can vary in their interpretation of the data from polls, which can lead to errors and possibly to polarization. As Page $(1978,32)$ comments: "Their are . . . many uncertainties in reading the tea leaves of public opinion, not the least of which is the nagging concern that given the low levels of information and imperfect question wording, poll results may be meaningless."

I am not contending that polls always provide "perfect" information. Clearly, for issues of little importance to the electorate, such as aid to Poland or price supports for farmers, public opinion would be tricky to interpret, even with access to good polling data. But for potentially realigning issues, it seems likely that polls will provide enough information to make this assumption reasonable. First, since potentially realigning issues will be, by definition, important to much of the public, respondents are likely to have clearer positions on them, which should lessen concerns about a poorly informed electorate. Second, if an issue arises that is powerful enough to forge a realignment, there will be a good number of polls available, both private and commercial, to provide politicians with lots of information regarding the issue. Sabato $(1981,68)$, for instance, reports that CBS and NBC conducted 65 public opinion surveys during the 1980 presidential campaign. Such a 
wealth of information should keep politicians from relying on any one misleading poll that might have led them to adopt an unpopular position. The popular press will also rely on polls in their discussion of the issues, supplying additional insights about public opinion. Moreover, if the findings of various polls disagree about the electorate's views, those discrepancies will trigger further surveys in an effort to sort out the differences among them. The final result should be well-informed politicians with roughly the same picture of the electorate, which should encourage them not to adopt polarizing positions on highly salient issues.

One might still contend that though less likely, polarization on highly salient issues is still possible. One cannot, of course, claim there is no chance of polarization. But such errors should be less common than prior to the development of survey research and realignments were rare events even before polls. Moreover, and perhaps just as important, polls provide evidence that allows politicians to correct errors made in the previous election. Thus, if parties adopt different views on an issue important to the public, poll results should provide evidence that would encourage the losing party to correct its mistake for the next election. These kinds of adjustments make polarization, even if it occurs, a short-term event, undercutting the prospect of significant partisan change.

While this argument may have some appeal, one might counter that in recent times parties have occasionally "polarized" on issues. The Goldwater and McGovern campaigns are two prime examples of where politicians, armed with polls, provided the electorate with a "choice, not an echo." These examples, however, do not, upon close examination, undermine my basic argument. To begin, while it is true that Goldwater and McGovern did adopt some unpopular positions on issues, it is not clear these positions were "extreme." Page (1978), for instance, argues that if one looks at the actual rhetoric of these candidates, their views on issues were not that far out of the mainstream. Kelley (1983) provides support for Page's position, showing that the electorate's rejection of these two candidates was more due to their personal qualities than to the adoption of "extreme" views on issues. In addition, Kessel (1968, 192-200) provides some evidence that polls did have the effect on the Goldwater campaign that my model predicts. For instance, in September 1964, Goldwater's strategists gathered survey data showing that social security and nuclear responsibility were two issues hurting the campaign. This evidence led Goldwater's aides to develop new television advertisements to address these problems. Now, of course, these responses did not stem LBJ's landslide, but it does show that in a supposedly "ideological" campaign polls were influential. McGovern also relied on polls to make political decisions during the campaign. Interestingly, Caddell's polls showed that McGovern's difficulties stemmed not from his views on issues, but from the public's doubts about his competency to be president (White 1973, 359). 
Thus, the senator from South Dakota did not need to adopt more moderate positions on issues, but instead needed to find a way to make himself appear more competent. ${ }^{9}$ Finally, Page (1978) presents some data indicating that these two contenders moderated their positions on issues in the fall campaign-behavior that is consistent with this theory.

One could still argue, however, that while polls played some role in these campaigns, the information from these surveys still did not prevent these two nominees from offering at least a few unpopular positions on issues. While these cases appear to cast doubt on my argument, the logic of this model does not require that parties adopt the same position on all issues. First, my argument applies only to potentially realigning issues. For issues of less importance to the public, parties can offer different views. Since these concerns, by definition, will not enter into the calculations of most voters, parties can risk offering nonmedian positions on then. Second, my argument only suggests that parties will adopt similar positions on highly salient issues. Or in other words, polls lead parties to lessen their differences, not end them. As a result, candidates like McGovern and Goldwater can appear on the political stage from time to time.

Interestingly, Ginsberg (1976, 41-44) provides some data supporting my contention that polarization has declined since the advent of polls. According to Ginsberg's content analysis of the Democratic and Republican platforms, there was a .017 average difference between the parties from 1940 to 1968 on their views on issues. ${ }^{10}$ So, as suggested above, parties have differed on some issues since the introduction of polls. But between 1844 and 1936, which one could term the prepoll era, the average difference between the parties' platforms was .073, which is over four times greater than that between 1940 and 1968. In addition, the frequency of "polarized" elections has dropped dramatically since the advent of polling. Of the eight elections from 1940 to 1968 , the Goldwater-Johnson contest exhibited the greatest difference between the parties' platforms: .041. No other election during this period approached that difference. But from 1844 to 1936 , more than $50 \%$ of the elections showed a greater difference between the parties' platforms than that witnessed in the 1964 campaign. In fact for those "polarized" contests from 1844 to 1936 the average difference was .175, which is more than a fourfold jump over the differences found in 1964. Thus, while the Johnson-Goldwater election is often seen as unusual in the "choice" it offered the electorate, Ginsberg's data suggest that such differences were common fare before the

\footnotetext{
${ }^{9}$ Kelley's (1983) systematic analysis of the 1972 presidential election confirms the interpretation that Caddell's polls suggested.

${ }^{10}$ I chose 1940 as the cut point since Gallup began its polling of the national electorate in 1937 and FDR started to use information from polls in 1939. Note that if one adopts later elections as starting points, it does not alter the basic finding.
} 


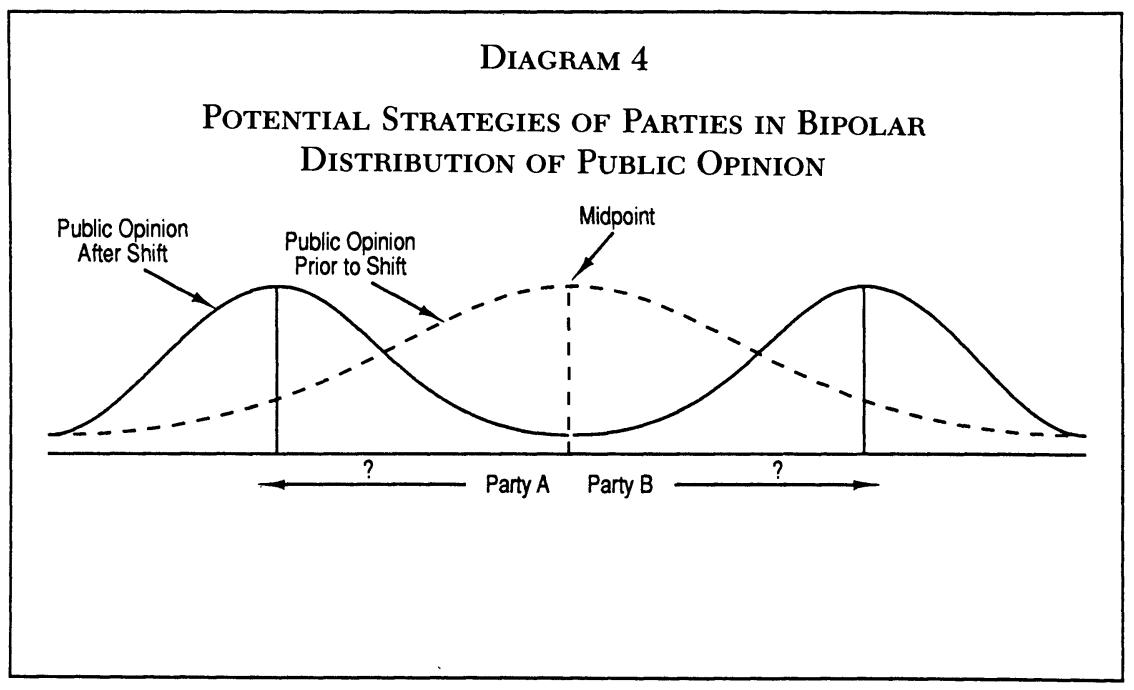

introduction of polls. These data, therefore, provide support for the fundamental conclusion of this paper: well-informed parties offer fewer differences on issues than poorly informed parties. ${ }^{11}$

Perhaps polarization need not come from the actions of parties, but instead from the electorate themselves. ${ }^{12}$ That is, one could argue that polarization might be inevitable regardless of how parties react, depending on the kind of change that occurs in the distribution of public opinion. If opinion is not normally distributed, but rather takes on a bipolar shape, the result might lead parties to adopt different positions on that issue (see diagram 4). Thus, the parties may be forced to take polarized positions, because of a sharp split in the electorate. Downs $(1957,118-19)$ reaches this conclusion.

\footnotetext{
${ }^{11}$ It is unfortunate that Ginsberg's data do not include the last five presidential elections. It is unlikely, however, that these contests would change the basic finding. Even is one assumes that every election from 1972 to 1988 had differences between the parties similar to those Ginsberg reports in 1964, which is highly unlikely given the Ford-Carter and Dukakis-Bush races, parties still differed about three times more on issues before polls than after them.

${ }^{12}$ If one moves beyond the traditional Downsian assumption that the party acts as a team, an additional source of polarization may arise. Specifically, polarization might come from the nominating system. Polsby (1983), for instance, contends that the current arragnement encourages factionalism. With factionalism, one extreme group could capture the party and polarize the political debate. If one assumes, however, that factions still seek to win elections, as most Downsian models would, these groups should still adopt positions on highly salient issues that maximize their chance for victory in the general election. And these positions, given the availability of polls, should not be polarizing. So regardless of the nominating system, polarization on highly salient issues can only emerge if one moves beyond the classic assumption that parties (or factions) seek to win elections.
} 
Such a strategy is not, however, rational for parties. First, both parties would still be better off competing at the center, because that would maximize their support. Even though nearly all voters would be dissatisfied with those positions, the rational voter would still choose between the lesser of two evils. More important, if one party (A) adopts a position in the center of one of the poles, a rational competitor (B) should move near that position and thus become the majority party (see diagram 5 ).$^{13}$ Thus, given the desire to win elections, rational parties should try to take similar positons on highly salient issues-regardless of the shape of public opinion. ${ }^{14}$

Another criticism of this paper's thesis is that I have assumed that a realignment has not occurred since the development of polls. While there is disagreement on this point, a good deal of evidence indicates that the New Deal Party System is still intact (Sundquist 1983; Carmines and Stimson 1989; Carmines, Renton, and Stimson 1984; Kelley 1988; Geer 1989). Clearly, there has been partisan change, as documented so well by Carmines and Stimson, but such change has not involved the emergence of a single issue that has forged a new party system. One might contend, for instance, that the erosion of the New Deal coalition signifies a realignment (Petrocik 1981), but that change can take place without parties polarizing on new issues. As Sundquist $(1983,448)$ argues, "when the New Deal alignment is strengthened, the New Deal coalitions are weakened, and vice versa." In other words, the white South, for example, should develop stronger ties to the more conservative GOP since people in that region generally do not support an activist federal government. Thus, changes in coalitions should be expected as demographic groups align themselves with the party that best represents their views.

Even if one wants to quarrel with the claim that no realignment has occurred, it appears that recent partisan change has been different from the realignments in the 1850s, 1890s, and 1930s. In each of those cases one can point to an issue on which the parties took opposing stands that helped generate change, such as slavery in the 1860 s or free-silver in the 1890 s. While the parties have not agreed on all issues that have surfaced over the last few decades, there has not been a major controversy that has led to a polarization

\footnotetext{
${ }^{13}$ Barry $(1970,114)$ make a similar point, arguing that a party which moves to the left to attract some extremist voters risks losing the election. If a party adopted that strategy, its opponent should match that position and thus secure a clear majority of the votes.

${ }^{14}$ One might argue that if parties take the center in a bipolar distribution, they could alienate enough voters to encourage the entrance of third parties into the fray. With competiton from the outside, the parties might be forced to take opposing positions in an effort to quell the attacks from insurgent groups. But in the United States, at least, third parties have a difficult time competing because of the election laws, which makes this possibility less likely (Rosenstone, Behr, and Lazarus 1984). Nonetheless, for the purposes of this argument, I shall assume a closed two-party system.
} 


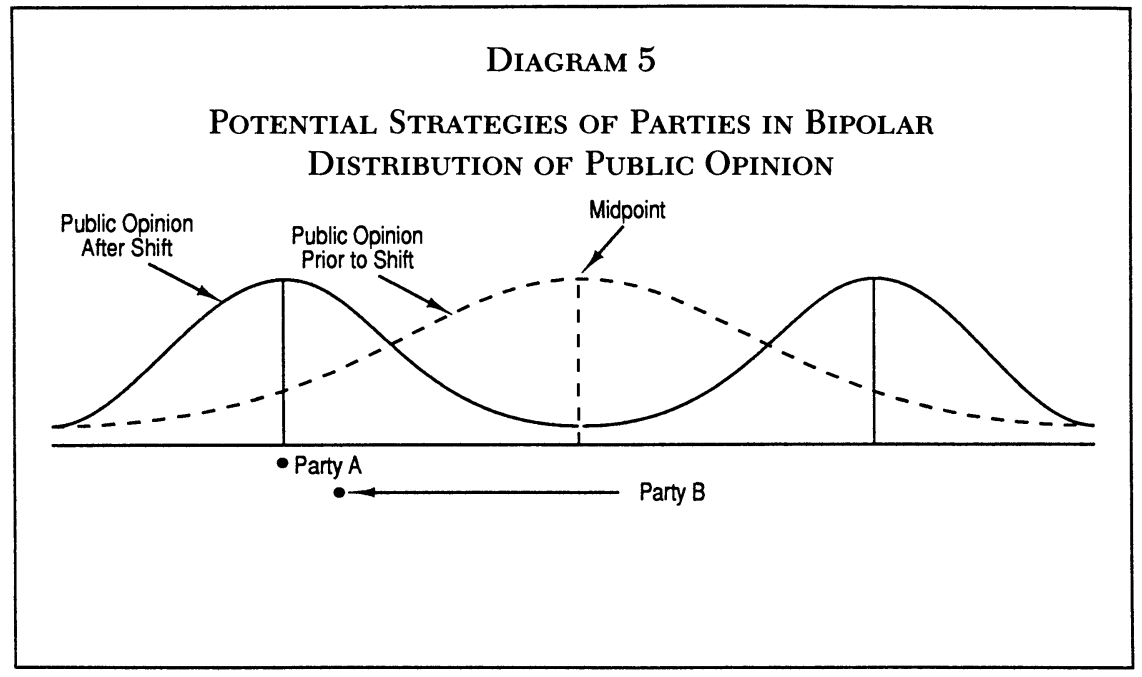

of the parties. Sundquist (1983), for instance, examines three divisive issues of the recent past (race relations, Vietnam, and the "social issue") and concludes that the parties "straddled" each of them-exactly what this theory would predict. In the case of Vietnam, Page and Brody $(1972,984)$ note that "there was . . . little difference between Nixon's and Humphrey's stated views on Vietnam policy." This war certainly could have brought about polarization, especially if one party had paid attention to the many protests that dotted the landscape of the country. But boisterous crowds no longer deceive politicians about the opinions of the entire electorate, as they once deceived William Jennings Bryan. ${ }^{15}$

Now, of course, one might argue that even if the parties had polarized on an issue such as abortion or Vietnam, a realignment would not have occurred. These issues were simply not salient enough to the public to reshape the party system. Certainly these issues were not as momentous as those associated with the Great Depression, but realigning issues need not possess such force. The issue of free-silver in the 1890s, for instance, was an impor-

${ }^{15}$ The issue of abortion may provide an interesting test for my argument. The GOP has clearly staked out an extreme position on abortion. And given that the Webster decision has increased the importance of this issue to the public, the GOP's nonmedian position on abortion may start costing them a large number of votes. The GOP is acutely aware of this problem, given public opinion polls. But the question is whether the GOP leadership will pay attention to the polls or will they remain committed to the position that many of the activists in the party hold so dear.

The handful of elections in 1989 suggest that GOP candidates did try to scramble toward the "center." But the better test will be the upcoming 1992 elections, especially if the Supreme Court raises the stakes even more by overturning Roe v. Wade. 
tant problem, but only part of the electorate appeared concerned about the matter-primarily the agrarian interests in the West and the financial interests in the East (Glad 1960, chap. 3). Yet the issue of free-silver realigned the party system. While one cannot be sure, it seems reasonable to believe that the Vietnam War, race relations, and the so-called "social issue" were at least as important to the public as the concern over monetary policy in the 1890s. In 1968, for instance, about half of the electorate, according to a survey from the National Election Studies, said that Vietnam was the most important problem facing the nation. It is also worth recalling that realignments need not entail massive change in the partisanship of the electorate. Only a portion of the public needs to change, either through conversion or mobilization, for a new party system to emerge (Andersen 1979). In sum, there is reason to believe that some of the issues since the Great Depression could have led to a critical realignment of the party system.

\section{CONCLUSION}

The public opinion poll has had great impact on the study of political science. Much of what we know about political behavior can be attributed to survey research. While polls supply the evidence for some of our most important theories about the behavior of the electorate, little effort has been made to consider how surveys might affect the behavior of politicians and the parties they represent. ${ }^{16}$ This paper represents one such attempt. Building on the idea that polls provide reliable information, this paper provides a new perspective on partisan change. The basic conclusion is that the availability of quality survey research should make it unlikely that rational parties will disagree radically on highly salient issues, thereby thwarting most potential critical realignments.

If so, political scientists should stop looking for critical realignments in the era of polls, since it is unlikely that any one election or even set of elections can be pointed to as realigning. ${ }^{17}$ Instead, partisan change should be considered a continuous rather than a dichotomous variable. The discipline, therefore, may want to focus much greater attention on the "gradual transformations of the party system" rather than "abrupt" change normally associated with the critical realignments of the past (Carmines and Stimson 1984, 152).

While critical realignments may be a thing of the past, partisan change still occurs. One mechanism for change arises from "low salience" issues. Parties,

\footnotetext{
${ }^{16}$ For one exception, see Keech and Matthews (1976). They contend that the advent of polls has lessened the uncertainty of party leaders when choosing a presidential nominee, since "now . . . they had reliable and objective measures of individual popularity" (8). Their argument is of interest, since they too argue that polls have altered the behavior of politicians.

${ }^{17}$ See also Carmines and Stimson (1989), Sundquist (1983), Clubb et al. (1980) for additional discussions of the problems facing the concept of critical realignment.
} 
depending on their preferences, can adopt different positions on issues like gun control or agricultural policy, since these concerns are only important to a small proportion of the electorate. Wittman (1983) makes this point, arguing that parties can pursue their preferred position on issues that are not central to winning elections. These differences, although minor, can chip away at the partisan loyalties of the electorate, generating slow piecemeal change that might look like Key's secular realignment or Carmines' and Stimson's "issue evolution."

Perhaps just as important as these conclusions is the model itself. That is, this paper provides an explicit explanation for why critical realignments occur. It builds on the arguments of previous empirical and theoretical work that highly salient issues forge partisan change. Using a spatial model to represent these realigning issues, this paper contends that the reactions of politicians to these important issues are central to the process (see, also, Sundquist 1983). Specifically, a realignment occurs when the leaderhip of the parties adopt polarized positions on a concern highly salient to the public, after which significant partisan change unfolds. And the party that correctly estimates public opinion becomes (or remains) the majority party. Certainly, if one believes that parties want to aviod becoming the minority party, it would be hard to explain why the leadership would stake out a losing position on a highly salient issue-unless they simply made a mistake. But, as noted so often above, such mistakes should be rare given the information available from public opinion polls, ushering in a new era of partisan change.

\section{Manuscript submitted 2 October 1989}

Final manuscript received 14 September 1990

\section{REFERENCES}

Aldrich, John H. 1983. “A Spatial Model with Party Activists: Implications for Electoral Dynamics." Public Choice 41:63-99.

Andersen, Kristi. 1979. The Creation of a Democratic Majority. Chicago: University of Chicago Press.

Anderson, David D. 1981. William Jennings Bryan. Boston: Twayne Publishers.

Barry, Brian. 1970. Sociologists, Economists and Democracy. Chicago: University of Chicago Press.

Burnham, Walter Dean. 1970. Critical Elections. New York: Norton.

Calvert, Randall L. 1985. "Robustness of the Multidimensional Voting Model: Candidate Motivations, Uncertainty and Convergence." American Journal of Political Science 29:69-95.

Carmines, Edward G., Steven H. Renton, and James A. Stimson. 1984. "Events and Alignments: The Party Image Link." In Controversies in Voting Behavior, ed. Richard G. Niemi and Herbert F. Weisberg. Washington DC: Congressional Quarterly Press.

Carmines, Edward G., and James A. Stimson. 1981. "Issue Evolution, Population Replacement and Normal Partisan Change." American Political Science Review 75:107-18.

Carmines, Edward G., and James A. Stimson. 1984. "The Dynamics of Issue Evolution: The 
United States." In Electoral Change in Advanced Industrial Democracies, ed. Russell Dalton, Scott Flanagan, and Paul Allen Beck. Princeton: Princeton University Press.

Carmines, Edward G., and James A. Stimson. 1989. Issue Evolution. Princeton: Princeton University Press.

Chappell, Henry W., and William R. Keech. 1986. "Policy Motivation and Party Differences in a Dynamic Spatial Model of Party Competition." American Political Science Review $80: 881-900$.

Clubb, Jerome M., William H. Flanigan, and Nancy H. Zingale. 1980. Partisan Realignment. Beverly Hills: Sage.

Colletta, Paolo E. 1968. “The Bryan Campaign of 1896.” In William Jennings Bryan, ed. Paul Glad. New York: Hill and Wang.

Downs, Anthony. 1957. An Economic Theory of Democracy. New York: Harper \& Row.

Drew, Elizabeth. 1981. Portrait of an Election. New York: Simon \& Schuster.

Farley, James A. 1938. Behind the Ballots. New York: Harcourt \& Brace.

Geer, John G. 1989. "Assessing Changes in the Public's Evaluations of the New Deal Party System." Presented at the annual meeting of the Midwest Political Science Association, Chicago.

Gienapp, William E. 1987. The Origins of the Republican Party, 1852-1856. New York: Oxford University Press.

Ginsberg, Benjamin. 1976. "Elections and Public Policy." American Political Science Review $70: 41-49$.

Glad, Paul W. 1960. The Trumpet Soundeth. Lincoln: University of Nebraska Press.

Herrera, Richard. 1989. "Party Goals and Party Behavior: An Examination of Ideology as a Party Goal." Presented at the annual meeting of the American Political Science Association, Atlanta.

Hollingsworth, J. Rogers. 1963. The Whirligig of Politics. Chicago: University of Chicago Press. Johnson, Donald Bruce, and Kirk H. Porter. 1973. National Party Platforms, 1840-1972. Urbana: University of Illinois Press.

Jones, Stanley L. 1964. The Presidential Election of 1896. Madison: University of Wisconsin Press.

Keech, William R., and Donald R. Matthews. 1976. The Party's Choice. Washington, DC: Brookings Institution.

Kelley, Stanley. 1983. Interpreting Elections. Princeton: Princeton University Press.

Kelley, Stanley. 1988. "Democracy and the New Deal Party System." In Democracy and the Welfare State, ed. Amy Gutmann. Princeton: Princeton University Press.

Kessel, John H. 1968. The Goldwater Coalition. New York: Bobbs-Merrill.

Key, V. O. 1955. "A Theory of Critical Elections." Journal of Politics 17:3-19.

Key. V. O. 1959. "Secular Realignment and the Party System." Journal of Politics 21:198-210.

Kleppner, Paul. 1987. Continuity and Change in Electoral Politics, 1893-1928. Westport, CT: Greenwood Press.

McCoy, Donald R. 1966. Landon of Kansas. Lincoln: University of Nebraska Press.

Mendelsohn, Harold, and Irving Crespi. 1970. Polls, Television, and the New Politics. Scranton, PA: Chandler Publishing.

Miller, Warren E. 1988. Without Consent. Lexington, KY: Kentucky University Press.

Moore, Jonathan, and Janet Fraser. 1977. Campaign for President. Cambridge: Ballinger Publishing.

Nimmo, Dan. 1970. The Political Persuaders. Englewood Cliffs, NJ: Prentice Hall.

Page, Benjamin I. 1978. Choices and Echoes in Presidential Elections. Chicago: University of Chicago Press.

Page, Benjamin I., and Richard A. Brody. 1972. "Policy Voting and the Electoral Process: The Vietnam War Issue." American Political Science Review 66:979-95. 
Petrocik, John R. 1981. Party Coalitions. Chicago: University of Chicago Press.

Polsby, Nelson. 1983. Consequences of Party Reform. Cambridge: Oxford University Press. Roll, Charles W., and Albert H. Cantril. 1972. Polls: Their Use and Misuse in Politics. New York: Basic Books.

Rosenstone, Steven J., Roy L. Behr, and Edward H. Lazarus. 1984. Third Parties in America. Princeton: Princeton University Press.

Sabato, Larry. 1981. The Rise of Political Consultants. New York: Basic Books.

Schattschneider, E. E. 1975. The Semisovereign People. Hinsdale, IL: Dryden Press.

Schlesinger, Arthur M. 1960. The Politics of Upheaval. Boston: Houghton Mifflin.

Schlesinger, James A. 1975. "The Primary Goals of Political Parties: A Clarification of Positive Theory." American Political Science Review 69:840-49.

Smithies, Arthur. 1941. "Optimum location in Spatial Competition." Journal of Political Economy 59:423-39.

Stokes, Donald E. 1966. "Spatial Models of Party Competition." In Elections and the Political Order, ed. Angus Campbell, Philip Converse, Warren Miller, and Donald Stokes. New York: Wiley.

Sundquist, James L. 1983. Dynamics of the Party System. Washington, DC: Brookings Institution.

Weed, Clyde P. 1989. "What Happened to the Republicans in the 1930s?" Polity 22:5-23.

White, Theodore H. 1973. The Making of the President 1972. New York: Atheneum.

Wirthlin, Richard, Vincent Breglio, and Richard Beal. 1981. "Campaign Chronicle." Public Opinion, Feb/March:43-49.

Wittman, Donald A. 1973. "Parties as Utility Maximizers." American Political Science Review $67: 490-98$.

Wittman, Donald A. 1983. "Candidate Motivation: A Synthesis of Alternative Theories." American Political Science Review 77: 142-57.

John G. Geer is assistant professor of political science, Arizona State University, Tempe, AZ 85287. 